\title{
The Effect of English Verbal Songs on Connected Speech Aspects of Adult English Learners' Speech Production
}

\author{
Farshid Tayari Ashtiani (Corresponding Author) \\ University of Guilan, Iran \\ E-mail: farshid.ashtiani@aol.com \\ Amir Mahdavi Zafarghandi \\ University of Guilan, Iran \\ E-mail: mahdavi1339@gmail.com
}

Doi:10.7575/aiac.alls.v.6n.1p.212

Received: $14 / 10 / 2014$

URL: http://dx.doi.org/10.7575/aiac.alls.v.6n.1p.212

Accepted: 02/01/2015

\begin{abstract}
The present study was an attempt to investigate the impact of English verbal songs on connected speech aspects of adult English learners' speech production. 40 participants were selected based on the results of their performance in a piloted and validated version of NELSON test given to 60 intermediate English learners in a language institute in Tehran. Then they were equally distributed in two control and experimental groups and received a validated pretest of reading aloud and speaking in English. Afterward, the treatment was performed in 18 sessions by singing preselected songs culled based on some criteria such as popularity, familiarity, amount, and speed of speech delivery, etc. In the end, the posttests of reading aloud and speaking in English were administered. The results revealed that the treatment had statistically positive effects on the connected speech aspects of English learners' speech production at statistical .05 level of significance. Meanwhile, the results represented that there was not any significant difference between the experimental group's mean scores on the posttests of reading aloud and speaking. It was thus concluded that providing the EFL learners with English verbal songs could positively affect connected speech aspects of both modes of speech production, reading aloud and speaking. The Findings of this study have pedagogical implications for language teachers to be more aware and knowledgeable of the benefits of verbal songs to promote speech production of language learners in terms of naturalness and fluency.
\end{abstract}

Keywords: English Verbal Songs, Connected Speech, Speech Production, Reading Aloud, Speaking

\section{Introduction}

Taking the advantages of music can generate an ideal atmosphere for language learning since songs can link the brain's hemispheres and make the retention more durable due to the supplementary functions as the right hemisphere acquires the melody while the left deals with the words. More generally, music in language teaching provides a rich-sounding atmosphere. This adumbrates that the musical approach is, at least, a possible educational option, which can strengthen the EFL learners' awareness of rhythm, sounds etc. Teachers can benefit this axiom that "all normal (non-braindamaged) people possess some musical intelligence" (Gardner, 1985, cited in Fonseca-Mora, Toscano-Fuentes \& Wermke, 2011, p.105), which assists learners in acquiring oral language capacities. Falioni (1993) also states, "Many people often remember rhyme, rhythm, and/or melody better than ordinary speech" (ibid. p.98). Through utilizing songs in the classroom "students concentrate on messages and ideas as they would in their native language" since "they are doing something with language: they are participating actively in the game called communication" (Murphey, 2010, p.242). In addition to getting familiar with cultural and linguistic elements, EFL learners, through listening to the songs and singing them can improve their listening and speaking skills in terms of foreign language sensitivity and awareness of phonology, which are the essential capacities necessary for a near-native-like communication.

Considering the paucity of research on the use of songs as a pedagogical tool in foreign language classrooms, the present study aimed at investigating the effect of English verbal songs on the connected speech aspects common in both singing and speech production in two speech modes of reading-aloud and speaking. Hence, an empirical study was conducted to measure specific benefits of songs on connected speech aspects and reduced forms.

\section{Review of Literature}

With a view to the comparison of acquiring music and speech, we must consider the correspondences between speech and music. Jean-Jacques Rousseau (1781) proposed that languages stemmed from music. According to him, music was a method of expressing feelings for the people inhabiting in warmer climates and without stress, and in the opposite side, sound and meaning split, and language turned out more symbolic for the people living in colder regions where life needed to be more organized. Graham (1969) describes foreign accent as being emerged from "speaking one language with the music of another, usually of one's mother tongue" (p. 446). Music and oral language production are of the same 
phenomena and thus possess some common features that can be used in second language teaching methods: the rhythm and melody of the music could be considered tantamount to stress and intonation (Arleo, 2000). Music and language can be divided into a hierarchical structure: in music, the whole structure goes from the larger constituent of a musical composition to the individual note, and in language, from the large units of discourse to the phonemes. Another resemblance, suggested by Arleo, is that "they follow a time line. The temporality of music, spoken language and other kinds of performances such as plays, poetry readings and dance, provides social cohesion by tying the participants together in a bounded collective experience" (Arleo, 2000, p.7).

Deutsch (1991) demonstrated that there is a connection between perceiving musical sounds and linguistic background. The notes, which were used in Deutsch's experiments, were elaborate tones bearing all octaves or a basic frequency. Twelve basses existed in all associating with the twelve notes of the chromatic scale. Notes were presented in pairs whose fundamentals were separated via tri-tones (six semitones or one-half octave). Participants were requested to recognize which of two tones had the higher basic frequency (pitch). It is noticeable that those from England perceived frequency values differently from participants from California. "If a Californian thinks that a $\mathrm{C}$ is above an $\mathrm{F}$ sharp, the Britisher will swear that F sharp is higher than the C (Seife, 2000, p. 2052).

Another reason, which demonstrates that there is a connection between music and language, is Amusia — "an inability to perceive music... (Balter, 2001, p. 1636). In the study, they did on the adults who were suffering from Amusia, Peretz et al. (1998) they showed that the mere reason correlating with this musical deficiency is a trouble in perception of pitch variations within speech. As a result, in case of an inability to realize music forecasts a problem in perception of speech, so there will be a correlation between perceiving music and speech.

\subsection{Music and Language Class with a Focus on Research}

Numerous authors (Foster, 1993; Guglielmino, 1986; Karimer, 1984; Lowe, 1998; Olhaver, 1998) states the merits which music holds and could be used in the classroom such as music for relaxation, concentration, motivation, cultural awareness, vocabulary acquisition, ear training and pronunciation. On the contrary of the endeavors done by language teachers for creating some varieties in their classes, high number of classes consist of drills, short dialogues and repetition. Guglielmino (1986, p.19) asserts, "ESL instruction, regardless of its focus, involves a great deal of drill and repetition". Since music provides pleasant repetitions in an enjoyable manner, it holds a great significance in a language class (Guglielmino, 1986).

Music and specially songs help learners, either possessing musical aptitude or not, to acquire words and sounds in an enjoyable manner. Language learners, regardless of their age, can always benefit the merits of the songs in or out of the classroom by singing and repeating them to improve their vocabulary and pronunciation. Some methods, such as Suggestopedia (Bancroft, 1982) and the method of Tomatis (Tomatis, 1991), take advantages of music to elevate relaxation and allow the learners to learn more efficiently. Other methods, such as the Contemporary Music Approach (Anton, 1990) and the KELP project (Johnson al., 1995), explore pop songs to encourage, motivate the students, and provide a more bustling and active ambience in the classroom.

Anton (1990) describes how the CMA (Contemporary Music Approach) uses songs in a Spanish classroom as an effective tool for memory.

CMA takes advantage of music - one of the most effective memory aids available to us. Through the songs, students learn rhythm, intonation, and pronunciation in a natural way as they listen to the music repeatedly and then attempt to reproduce the sound they hear (Anton, 1990, p. 1169).

\subsection{Music, Pronunciation, and Research}

Most adults learning a foreign language usually speak along with an accent, which is derived from phonetic and phonological disparities between their first language and the second language. Music and songs could be fruitful in honing phonetic skills in various ways. Leith (1979) stated, "There is probably not a better, nor quicker way to teach phonetics than with songs" (p. 540). Gatti-Taylor (1980) believed that phonetic instruction could be both easy and enjoyable, stating, "It is relatively easy to find song lyrics that stress a particular phoneme" (p. 466). García-Sáez (1984) agreed stating, "the use of song is an excellent way to practice Spanish phonetics and it is not at all difficult to find examples of songs that contain sounds the majority of students have trouble producing" (p. 4). The melody, composed with the lyrics, creates an excellent opportunity to review pronunciation and appreciate the song simultaneously. Poliquin (1988) accentuates the value and positive penetration of songs in language instruction that should be used perceptively to enhance pronunciation skills. He reiterates that comprehending the semantic issues is monitored by the left hemisphere and musical sounds and rhythms by the right. He advised the pedagogical benefits of using songs to develop cognitive skills to show the connection of rhythm of spoken language and song rhythm. Karimer (1994) did a study on ESL learners to find out if acquiring a native-like fluency could be faster and better through using nursery rhymes, chants, and songs.

Thain (2010) emphasizes the use of songs in lessons since songs help developing the four skills and believes that songs bring about activation of both sides of the brain.

Many scholars have found euphoric correspondences between songs and memory: Murphey (1990) defines the 'songstuck-in-my-head' phenomenon as a melodic Din like a voluntary musical and verbal rehearsal. Falioni (1993, p. 98) 
asserts, "Many people often remember rhyme, rhythm and/or melody better than ordinary speech", particularly when the content is important for them.

Crookes and Schmidt (1991) realized four motivational elements in foreign language learning including interest in the lesson, relevance, expectation, and satisfaction. Moreno et al. (2009) studied the effects of music on learners' language development and found that exercising musical tasks for even a short duration could positively influences the ability to perceive and differentiate individual phonemes of the language. Music training enhances aural skills (Kraus \& Chandrasekaran, 2010) as well as verbal memory (Chan \& Cheung, 1998). Kids having a weak phonemic intelligence in first language (Ehri et al., 2001) revealed lower levels of progress respecting learning of foreign languages (Hu, 2003).

Another remarkable element to be considered is cultural sensitivity because songs usually represent cultural elements. Abbott (2002, p. 10) suggests, "cultures have musical traditions because of the enjoyment people receive from creating rhythms and expressing their feelings, ideas, thoughts, and cultural values through lyrics". Songs are one of the sources of cultural and linguistic items with respect to second or foreign language learning. Many factors such as attitudes towards the country where the language is spoken, its culture and customs are influential in acquisition of that language. When the learners of that language are out of that country, songs put an enjoyable and effective way to introduce the culture and encourage students (Murphey, 2010).

\subsection{Songs and Connected Speech}

Griffee (1995, p.28)asserts that "connected speech is the natural way we speak, linking together and emphasizing certain words, rather than each word standing alone". On the opposite of the importance role of connected speech in spoken English, it is not as authentic as reality in English lessons. "Many learners are accustomed to hearing a very careful, clear pronunciation of words, such as native speakers might use when talking very emphatically or saying words in isolation" (Rixon, 1986, p. 38). This is while native speakers connect the words and sounds in their speech.

The other misunderstanding is that learners usually consider contractions as incorrect and used in slang. However, as said before, native speakers utter the words purposefully in divisions to emphasize and this means that connected speech is a natural and normal occurrence in their spoken language. Songs assist learners to exercise through providing actual and catchy examples of pronouncing whole phrases to the extent that they prefer it than uttering separated as individual words. Brown and Kondo-Brown (2006a) mention that connected speech makes up "a very real part" (p. 5) of the spoken language and occurs in "all levels of speech" (p. 5) from casual to even very formal levels.

Dauer and Browne (1992) contend that enabling the speaker to not only improve his/her intelligibility by making the total rhythm of speech better but also causing psychological relief and confidence are of benefits of producing connected speech which makes speech more natural. Non-existence of connected speech could engender the speech of a non-native speaker sounds choppy and unnatural and discourage the listener (Brown, 2001; Celce-Murcia et al., 1996).

Ito (2006b) describes the way speakers of other languages agree on the difference of connected speech from what they usually have heard in their language classes before. Because the spoken language of the teacher and audio materials are slowly articulated. Accordingly, exposing and inspiring the learners with abundance of connected speech through songs could be an effective, simple, and enjoyable manner.

In the teaching pronunciation premiere, many pronunciation textbooks are increasingly covering and introducing the issues of connected speech (e.g., Hagen, 2000; Weinstein, 2001). Connected speech is a phenomenon to be occurred in spoken language and includes phonological processes such as reduction, elision, assimilation, and contraction. Many research studies demonstrated that instructing connected speech can assist learners in comprehension of speeches with rapid delivery (e.g., Brown \& Hilferty, 2006; Celce-Murcia, Brinton, \& Goodwin, 1996; Matsuzawa, 2006). More importantly, exercising features of connected speech can help non-native speakers to have a more natural and comprehensible speech with less marked foreign accent (Brown \& Kondo-Brown, 2006; Dauer\& Browne, 1992). Although compared to the literature of connected speech that is on a growth about the ways and forms to be taught, there is not enough information on how to manipulate the connected speech in terms of production.

In comparison to the studies done on connected speech and perception, not many studies have worked on the connected speech in terms of production to find ways to make spoken language more natural and fluent phonologically, and to see if it could be taught and enhanced via a musical instruction such as singing songs. More studies that are comprehensive are needed to investigate the effect of songs on connected speech aspects of speech production of language learners. The present study might be considered significant as it attempted to bridge this gap in the literature.

\section{Research Questions}

The present study intends to investigate the effects of English verbal songs on connected speech aspects of English learners' speech production. As such, the following research questions are raised:

Q1: Do English verbal songs have positive effects on the connected speech aspects of adult English learners' speech production at .05 statistical significant level?

Q2: On which speech production mode; reading-aloud or speaking, do English verbal songs have more positive effects in terms of connected speech aspects at .05 statistically significant level? 


\section{Method}

In an attempt to investigate the effect of English verbal songs on connected speech aspects of adult English learners' speech production, a detailed description of participants, instrumentation, procedure, design, and statistical analysis of the study would follow.

\subsection{Participants}

The participants of the study were forty adult intermediate level male students with the age range of 18 to 25 at a language institute in Tehran. These participants were chosen from 60 intermediate students attending English conversation classes according to their performance on a sample NELSON test, which was first piloted with 30 students with similar characteristics to the main participants of the study in order to check its reliability, and then the test was administered.

The students who did not meet the criterion also were allowed to participate in the study, but their scores were not included in the related analyses of the study. The selected participants were divided into two groups: One experimental group and one control group with 20 students in each, consisting of 20 students in each class. All the participants had studied English courses in the public school system requiring uniformity all over the country. Therefore, the researcher's expectation in terms of the learners' language proficiency level was met to a high extent, as they did not differ so much in this regard.

\subsection{Instrumentation}

The data for the present study was collected by means of three tests: a NELSON, a pre and posttest of reading-aloud, and a pre and posttest of speaking.

The speaking test used as pre and posttests was selected from the sample-structured interview questions of the intermediate speaking test of TESOL developed, validated, and presented by Lancaster University available at www.lancaster.ac.uk/fass/projects/.../InterviewQ.pdf. The participants' voices in both pre and posttests of speaking were recorded and rated by two raters, the researcher himself and a PhD student of TEFL who had studied and lived in England for years and had been teaching English in university. The raters scored the participants' performances based on the band descriptor provided for rating connected speech features. The texts used for pre and posttests were the intermediate reading comprehension texts selected from http:/www.boostyourenglishscore.com. At first, a pretest of reading-aloud skill was given to the participants in both control and experimental groups. This task was to assess the oral presentation of a written text (reading-aloud skill) in a way that the participants in each group were given an identical passage appropriate to their level and had a couple of minutes to take a glance at it. Then they read it aloud and their voices were recorded. For the posttest, the same text in the pretest was given to the participants to be read aloud and recorded again. The participants' voices in both pre and posttests of reading-aloud were recorded and rated by the two raters using a band descriptor of the four connected speech aspects under the study prepared by the researcher.

\subsection{Procedure}

\subsubsection{Pretest Phase}

The first phase in the pretest section was the pilot study during which 30 intermediate students with similar features to the target sample took the sample NELSON test used for homogenizing. In the second phase of the pretest section, the participants were selected. Next, the pilot NELSON was administered to 60 intermediate students to homogenize them regarding their general English proficiency. Out of 60 students, 40 students whose scores had fallen one standard deviation above and below the mean shaped the main participants of the study. The selected participants were randomly assigned to the two groups, an experimental and a control group with 30 students in each. It is worth mentioning that, due to the nature of the convenient non-random sampling of the samples, the eliminated students were attending the classes, but their scores on the pre, and posttests were not included in the study. In the third phase of pretesting, the participants of the study in both groups took the pretests of reading-aloud and speaking.

\subsubsection{Intervention Phase}

The intervention took 18 sessions. The whole term included seven weeks and the learners attended the classes three days a week, each session lasting for 90 minutes in both groups. Considering the fact that the syllabus of the language school had to be covered during the term, eighteen sessions were allocated to the experiment in the experimental group. Therefore, the classes of control and experimental groups received the same hours of instruction and practice. In addition, the researcher himself taught both groups. Furthermore, listening and speaking practices based on the activities of the textbook (American English File) were used for both groups.

In the experimental group, at the end of each two sessions, one song was worked out. Accordingly, 9 songs were practiced altogether. Teaching new grammar or lexis contained in the text was not the goal as merely working on some aspects of phonology was addressed. Although the meaning of the text was explained orally in the target language in order for a better connection with the song, but they were not translated or explained in the learners' L1.

The control group was taught through the instructional conversations that arose between teachers and learners during the normal classroom pedagogical activities. In this group, there was no specific focus on songs to make the learners sensitive to the pronunciation of the words. Unlike the experimental group in which the teacher used the songs and their respective listening strategies, the control group was not exposed to songs. Instead, the learners dealt with routine practices of listening comprehension and speaking, sound perception, and meaning orientation. The learners were 
supposed to listen to the texts and answer the questions or repeat what they had heard. In addition, the learners worked on the vocabulary they heard in the listening texts. The pronunciation, intonation, and diction were also taken into consideration.

\subsubsection{Posttest Phase}

At the end of the treatment and the term, the posttests of reading-aloud and speaking were administered to the two groups to see if there were any significant differences in their respective abilities. Two raters scored the participants' performances on both tasks and the data gathered was analyzed using SPSS version 21, the results of which will follow.

\section{Data Analyses and Results}

\subsection{Testing Assumptions}

The present data were analyzed through the parametric tests of independent, paired-samples t-test, and multivariate ANOVA, which are based on four main assumptions of interval data, independence of subjects, normality, and homogeneity of variances. The first two assumptions do not have a statistical test. The data are measured on an interval scale and the subjects performed on the tests independently. The normality assumption was met. As displayed in Table 1 the ratios of skewedness and kurtosis over their respective standard errors were within the ranges of $+/-1.96$.

Table 1. Testing Normality Assumption

\begin{tabular}{|c|c|c|c|c|c|c|c|c|}
\hline \multirow[t]{2}{*}{ Group } & & \multicolumn{2}{|l|}{$\mathrm{N}$} & \multicolumn{2}{|l|}{ Skewness } & \multicolumn{3}{|c|}{ Kurtosis } \\
\hline & & Statistic & Statistic & Std. Error & Ratio & Statistic & Std. Error & Ratio \\
\hline \multirow{6}{*}{ Experimental } & NELSON & 20 & -.107 & .512 & -0.20 & -.979 & .992 & -.986 \\
\hline & PreRA & 20 & -.058 & .512 & -0.11 & .133 & .992 & 0.13 \\
\hline & PostRA & 20 & -.579 & .512 & -1.13 & -1.047 & .992 & -1.06 \\
\hline & PreSP & 20 & -.104 & .512 & -0.20 & -.059 & .992 & -0.06 \\
\hline & PostSP & 20 & -.927 & .512 & -1.81 & 1.207 & .992 & 1.22 \\
\hline & Valid N (listwise) & 20 & & & & & & \\
\hline \multirow[t]{6}{*}{ Control } & NELSON & 20 & .508 & .512 & .992 & -1.143 & .992 & -1.14 \\
\hline & PreRA & 20 & .270 & .512 & 0.53 & -1.091 & .992 & -1.10 \\
\hline & PostRA & 20 & .612 & .512 & 1.20 & -.828 & .992 & -0.83 \\
\hline & PreSP & 20 & .810 & .512 & 1.58 & .494 & .992 & 0.50 \\
\hline & PostSP & 20 & -.699 & .512 & -1.37 & 1.213 & .992 & 1.22 \\
\hline & Valid N (listwise) & 20 & & & & & & \\
\hline
\end{tabular}

Note. PreRA $=$ Pretest of Reading Aloud, PreSP $=$ Pretest of Speaking

The assumption of homogeneity of variances will be discussed when reporting the results of the independent t-test and MANOVA.

\subsection{Pretest of Reading-aloud}

An independent t-test was run to compare the Experimental and control groups' mean scores on the pretest of reading aloud in order to show that both groups were at the same level of reading-aloud ability prior to the administration of the treatment. As displayed in Table 2, the experimental $(\mathrm{M}=71.25, \mathrm{SD}=7.43)$ and control $(\mathrm{M}=71.28, \mathrm{SD}=5.92)$ groups showed almost the same means on the pretest of reading aloud.

Table 2. Descriptive Statistics Pretest of Reading-aloud by Groups

\begin{tabular}{lcccc}
\hline Group & N & Mean & Std. Deviation & Std. Error Mean \\
\hline Control & 20 & 71.28 & 5.928 & 1.326 \\
\hline Experimental & 20 & 71.25 & 7.438 & 1.663 \\
\hline
\end{tabular}

The results of the independent t-test $(\mathrm{t}(38)=.012, \mathrm{P}>.05, \mathrm{R}=.002)$ representing a weak effect size) (Table 3) indicated that there was not any significant difference between the two groups' mean scores on the pretest of readingaloud. Thus, it can be concluded that they enjoyed the same level of reading-aloud ability prior to the administration of the treatment. 
Table 3. Independent t-test Pretest of Reading Aloud by Groups

\begin{tabular}{|c|c|c|c|c|c|c|c|c|c|}
\hline & \multicolumn{2}{|c|}{$\begin{array}{c}\text { Levene's Test for } \\
\text { Equality of } \\
\text { Variances }\end{array}$} & \multicolumn{7}{|c|}{ t-test for Equality of Means } \\
\hline & \multirow[t]{2}{*}{$\mathrm{F}$} & \multirow[t]{2}{*}{ Sig. } & \multirow[t]{2}{*}{$\mathrm{T}$} & \multirow[t]{2}{*}{ Df } & \multirow[t]{2}{*}{$\begin{array}{l}\text { Sig. (2- } \\
\text { tailed) }\end{array}$} & \multirow[t]{2}{*}{$\begin{array}{c}\text { Mean } \\
\text { Difference }\end{array}$} & \multirow[t]{2}{*}{$\begin{array}{l}\text { Std. Error } \\
\text { Difference }\end{array}$} & \multicolumn{2}{|c|}{$\begin{array}{l}95 \% \text { Confidence } \\
\text { Interval of the } \\
\text { Difference }\end{array}$} \\
\hline & & & & & & & & Lower & Upper \\
\hline $\begin{array}{c}\text { Equal variances } \\
\text { assumed }\end{array}$ & .482 & .492 & .012 & 38 & .991 & .025 & 2.127 & -4.281 & 4.331 \\
\hline $\begin{array}{c}\text { Equal variances } \\
\text { not assumed }\end{array}$ & & & .012 & 36.198 & .991 & .025 & 2.127 & -4.288 & 4.338 \\
\hline
\end{tabular}

It should be noted that the assumption of homogeneity of variances was met (Levene's $F=.482, p>.05$ ). That is why the first row of Table 3, i.e. "Equal variances assumed" was reported.

\subsection{Pretest of Speaking}

An independent t-test is run to compare the Experimental and control groups' mean scores on the pretest of speaking in order to show that both groups were at the same level of speaking ability prior to the administration of the treatment. As displayed in Table 4the experimental $(\mathrm{M}=54.90, \mathrm{SD}=3.23)$ and control $(\mathrm{M}=54.63, \mathrm{SD}=4.14)$ groups showed almost the same means on the pretest of speaking.

Table 4. Descriptive Statistics Pretest of Speaking by Groups

\begin{tabular}{ccccc}
\hline Group & $\mathrm{N}$ & Mean & Std. Deviation & Std. Error Mean \\
\hline Control & 20 & 54.63 & 4.142 & .926 \\
\hline Experimental & 20 & 54.90 & 3.239 & .724 \\
\hline
\end{tabular}

The results of the independent $\mathrm{t}$-test $(\mathrm{t}(38)=.234, \mathrm{P}>.05, \mathrm{R}=.038$ representing a weak effect size) (Table 5) indicated that there was not any significant difference between the two groups' mean scores on the pretest of speaking. Thus, they must have been at the same level of speaking ability prior to the administration of the treatment.

Table 5. Independent t-test Pretest of Speaking by Groups

\begin{tabular}{|c|c|c|c|c|c|c|c|c|c|}
\hline & \multicolumn{2}{|c|}{$\begin{array}{c}\text { Levene's Test for } \\
\text { Equality of } \\
\text { Variances }\end{array}$} & \multicolumn{7}{|c|}{ t-test for Equality of Means } \\
\hline & \multirow[t]{2}{*}{$\mathrm{F}$} & \multirow[t]{2}{*}{ Sig. } & \multirow[t]{2}{*}{$\mathrm{T}$} & \multirow[t]{2}{*}{$\mathrm{Df}$} & \multirow[t]{2}{*}{$\begin{array}{l}\text { Sig. (2- } \\
\text { tailed) }\end{array}$} & \multirow[t]{2}{*}{$\begin{array}{c}\text { Mean } \\
\text { Difference }\end{array}$} & \multirow[t]{2}{*}{$\begin{array}{l}\text { Std. Error } \\
\text { Difference }\end{array}$} & \multicolumn{2}{|c|}{$\begin{array}{l}95 \% \text { Confidence } \\
\text { Interval of the } \\
\text { Difference }\end{array}$} \\
\hline & & & & & & & & Lower & Upper \\
\hline $\begin{array}{c}\text { Equal variances } \\
\text { assumed }\end{array}$ & .934 & .340 & .234 & 38 & .816 & .275 & 1.176 & -2.105 & 2.655 \\
\hline $\begin{array}{c}\text { Equal variances } \\
\text { not assumed }\end{array}$ & & & .234 & 35.912 & .816 & .275 & 1.176 & -2.110 & 2.660 \\
\hline
\end{tabular}

It should be noted that the assumption of homogeneity of variances was met (Levene's $\mathrm{F}=.964, \mathrm{P}>.05$ ). That is why the first row of Table 5, i.e. "Equal variances assumed" was reported.

\subsection{Answers to the Research Questions}

Research Question 1: Do English verbal songs have statistically significant positive effects on the connected speech aspects of adult English learners' speech production?

A multivariate ANOVA (MANOVA) was run to investigate the effect of English verbal songs on the connected speech aspects of adult English learners' speech production (reading-aloud and speaking). Before reporting the main results, it should be noted that the assumption of homogeneity of variances - as tested through the Levene's F-values - and the assumption of homogeneity of covariance - as tested through the Box's test - are met. As displayed in Table 6, the 
probabilities associated with the Levene's F-values are all higher than .05 . Thus, the assumption of homogeneity of variances is met.

Table 6. Levene's Test of Equality of Error Variances

\begin{tabular}{lcccc}
\hline & F & df1 & df2 & Sig. \\
\hline PostRA & 1.456 & 1 & 38 & .125 \\
PostSP & 1.219 & 1 & 38 & .276 \\
\hline
\end{tabular}

Besides, showing homogenous variances, the groups should have homogenous covariance matrices. The Box's M-value of 5.97 was not significant $(\mathrm{P}>.05)$. Thus, the assumption of homogeneity of covariance matrices was also met.

Table 7. Box's Test of Equality of Covariance Matrices

\begin{tabular}{lc}
\hline Box's M & 5.972 \\
F & 1.877 \\
df1 & 3 \\
df2 & 259920.000 \\
Sig. & .131 \\
\hline
\end{tabular}

Based on the results displayed in Table 8, it can be said that English verbal songs had significant effects on the connected speech aspects of adult English learners' speech production $(\mathrm{F}(2,37)=186.07, \mathrm{P}<.05$, Partial $\eta 2=.91$ representing a large effect size). Accordingly, the first null-hypothesis was rejected.

English verbal songs had statistically significant positive effects on the connected speech aspects of adult English learners' speech production.

Table 8. Multivariate Tests

\begin{tabular}{llcccccc}
\hline Effect & & Value & F & Hypothesis df & Error df & $\begin{array}{c}\text { Sig. } \\
\text { Partial Eta } \\
\text { Squared }\end{array}$ \\
\hline Intercept & Pillai's Trace & .998 & 10394.580 & 2 & 37 & .000 & .998 \\
& Wilks' Lambda & .002 & 10394.580 & 2 & 37 & .000 & .998 \\
& Hotelling's Trace & 561.869 & 10394.580 & 2 & 37 & .000 & .998 \\
& Roy's Largest Root & 561.869 & 10394.580 & 2 & 37 & .000 & .998 \\
\multirow{5}{*}{ Group } & Pillai's Trace & .910 & 186.074 & 2 & 37 & .000 & .910 \\
& Wilks' Lambda & .090 & 186.074 & 2 & 37 & .000 & .910 \\
& Hotelling's Trace & 10.058 & 186.074 & 2 & 37 & .000 & .910 \\
& Roy's Largest Root & 10.058 & 186.074 & 2 & 37 & .000 & .910 \\
\hline
\end{tabular}

As displayed in Table 9, the experimental group's means on Reading-aloud $(\mathrm{M}=84.77)$ and speaking $(\mathrm{M}=87.75)$ were significantly higher than thos of the control group (76.85 and 61.75). These results suggest that the English verbal songs improved connected speech aspects of adult English learners.

Table 9. Descriptive Statistics

\begin{tabular}{|c|c|c|c|c|c|}
\hline \multirow[t]{2}{*}{ Dependent Variable } & \multirow[t]{2}{*}{ Group } & \multirow[t]{2}{*}{ Mean } & \multirow[t]{2}{*}{ Std. Error } & \multicolumn{2}{|c|}{$95 \%$ Confidence Interval } \\
\hline & & & & Lower Bound & Upper Bound \\
\hline \multirow[t]{2}{*}{ PostRA } & Experimental & 84.775 & 1.352 & 82.039 & 87.511 \\
\hline & Control & 76.850 & 1.352 & 74.114 & 79.586 \\
\hline \multirow[t]{2}{*}{ PostSP } & Experimental & 84.750 & .844 & 83.041 & 86.459 \\
\hline & Control & 61.750 & .844 & 60.041 & 63.459 \\
\hline
\end{tabular}

Research Question 2: On which speech production mode; reading-aloud or speaking, do English verbal songs have more significantly positive effects in terms of connected speech aspects at .05 statistical level ? 
A paired-samples t-test was run to compare the Experimental group's mean scores on the posttests of reading-aloud and speaking in order to probe the second research question. As displayed in Table 10, the experimental group showed almost the same means on posttest of reading-aloud $(\mathrm{M}=84.78, \mathrm{SD}=7.15)$ and posttest of speaking $(\mathrm{M}=84.75, \mathrm{SD}=$ 4.38).

Table 10. Descriptive Statistics Posttests of Reading Aloud and Speaking

\begin{tabular}{lcccc}
\hline & N & Mean & Std. Deviation & Std. Error Mean \\
\hline Reading Aloud & 20 & 84.78 & 7.157 & 1.600 \\
\hline Speaking & 20 & 84.75 & 4.387 & .981 \\
\hline
\end{tabular}

The results of the paired-samples t-test $(\mathrm{t}(19)=.031, \mathrm{P}>.05, \mathrm{R}=.009$ representing a weak effect size) (Table 11$)$ indicate that there was not any significant difference between the experimental group's mean scores on the posttests of reading-aloud and speaking. Thus, the second null-hypothesis is approved.

Table 11. Paired-Samples t-test Posttests of Reading Aloudand Speaking

\begin{tabular}{|c|c|c|c|c|c|c|c|}
\hline \multicolumn{5}{|c|}{ Paired Differences } & \multirow[t]{3}{*}{$\mathrm{t}$} & \multirow[t]{3}{*}{$\mathrm{df}$} & \multirow[t]{3}{*}{ Sig. (2-tailed) } \\
\hline \multirow[t]{2}{*}{ Mean } & \multirow[t]{2}{*}{ Std. Deviation } & \multirow[t]{2}{*}{$\begin{array}{l}\text { Std. Error } \\
\text { Mean }\end{array}$} & \multicolumn{2}{|c|}{$\begin{array}{l}95 \% \text { Confidence Interval of the } \\
\text { Difference }\end{array}$} & & & \\
\hline & & & Lower & Upper & & & \\
\hline .025 & 8.328 & 1.862 & -3.873 & 3.923 & .013 & 19 & .989 \\
\hline
\end{tabular}

\subsection{Construct Validity}

A factor analysis was run to probe the construct validity of the tests employed in this study. The SPSS extracted two factors, which accounted for 66.93 percent of the total variance.

Table 12. Total Variance Explained

\begin{tabular}{lccccccccc}
\hline Component & \multicolumn{3}{c}{ Initial Eigenvalues } & \multicolumn{3}{c}{$\begin{array}{c}\text { Extraction Sums of Squared } \\
\text { Loadings }\end{array}$} & \multicolumn{3}{c}{$\begin{array}{c}\text { Rotation Sums of Squared } \\
\text { Loadings }\end{array}$} \\
\cline { 2 - 10 } & Total & $\begin{array}{c}\text { \% of } \\
\text { Variance }\end{array}$ & $\begin{array}{c}\text { Cumulative } \\
\%\end{array}$ & Total & $\begin{array}{c}\text { \% of } \\
\text { Variance }\end{array}$ & $\begin{array}{c}\text { Cumulative } \\
\%\end{array}$ & Total & $\begin{array}{c}\text { \% of } \\
\text { Variance }\end{array}$ & $\begin{array}{c}\text { Cumulative } \\
\%\end{array}$ \\
\hline 1 & 2.155 & 43.103 & 43.103 & 2.155 & 43.103 & 43.103 & 1.960 & 39.191 & 39.191 \\
2 & 1.192 & 23.833 & 66.936 & 1.192 & 23.833 & 66.936 & 1.387 & 27.745 & 66.936 \\
3 & .798 & 15.969 & 82.904 & & & & & & \\
4 & .790 & 15.804 & 98.708 & & & & & & \\
5 & .065 & 1.292 & 100.000 & & & & & & \\
\hline
\end{tabular}

Extraction Method: Principal Component Analysis.

Table 13 below displays the factor loadings of the tests under the extracted factors:

Table 13. Rotated Component Matrix

\begin{tabular}{lcc}
\hline & \multicolumn{2}{c}{ Component } \\
\cline { 2 - 3 } & 1 & 2 \\
\hline PostRA & .934 & \\
PreRA & .891 & \\
NELSON & -.426 & -.393 \\
PreSP & & .772 \\
PostSP & & .754 \\
\hline
\end{tabular}




\subsection{Inter-Rater Reliability Indices}

There was a significant agreement between the raters on rating; pretest of reading-aloud $(\mathrm{r}(38)=.97, \mathrm{P}<.05)$, posttest of reading-aloud $(\mathrm{r}(38)=.61, \mathrm{P}<.05)$, pretest of speaking $(\mathrm{r}(38)=.97, \mathrm{P}<.05)$ and posttest of speaking $(\mathrm{r}(38)=.85$, $\mathrm{P}<.05)$.

Table14: Inter-Rater Reliability Indices

\begin{tabular}{|c|c|c|c|c|c|}
\hline & & PreRAR2 & PostRAR2 & PreSPR2 & PostSPR2 \\
\hline \multirow[t]{3}{*}{ PreRAR1 } & Pearson R & $.977^{* *}$ & & & \\
\hline & $\mathrm{P}$ & .000 & & & \\
\hline & $\mathrm{N}$ & 40 & & & \\
\hline \multirow[t]{3}{*}{ PostRAR1 } & Pearson R & & $.610^{* *}$ & & \\
\hline & $\mathrm{P}$ & & .000 & & \\
\hline & $\mathrm{N}$ & & 40 & & \\
\hline \multirow[t]{3}{*}{ PreSPR1 } & Pearson R & & & $.971^{* *}$ & \\
\hline & $\mathrm{P}$ & & & .000 & \\
\hline & $\mathrm{N}$ & & & 47 & \\
\hline \multirow[t]{3}{*}{ PostSPR1 } & Pearson R & & & & $.853^{* *}$ \\
\hline & $\mathrm{P}$ & & & & .000 \\
\hline & $\mathrm{N}$ & & & & 49 \\
\hline
\end{tabular}

\section{Discussion}

The findings of the present study suggest that English verbal songs have statistically significant positive effects on the connected speech aspects of adult English learners' speech production. Meanwhile, there was not any significant difference between the experimental group's mean scores on the posttests of reading-aloud and speaking. Thus, it can be argued that there is no significant difference between improvements in reading-aloud and that in speaking considering the amount of received positive effects from English verbal songs.

The findings of the study are in line with the findings of other studies claiming that employing music in second language teaching has proved effective in general. Murphey (2010) argues that listening to songs and singing them improves listening and speaking skills. Employing music and songs enrich sensitivity and awareness to issues of phonology in a foreign language, the essential capacities necessary for a near-native-like communication (Falioni, 1993). Previous findings on the effect of having more access to songs in English and music in the ESL classroom vastly support the findings (Cormier's, 1985; Eckman, et al, 2014; Gatti-Taylor, 1980; Karimer, 1994; Knight, 2012; Lyczak, 1979; Medina, 1990; Salcedo, 2010). In a study done by Fitzgerald (1994), after a study of 23 Spanish students in an English bilingual program where they had to sing in either Spanish or English from the outset, he found that the participants' pronunciation, their reading skills, and participation all benefited. Furthermore, Moreno et al. (2009) found that "musical training influences linguistic abilities" (p.720) and Murphey (2010) found that using music and songs were more apt to facilitate the process of listening comprehension than the ordinary teaching of this skill. According to Arnold (1999), "we learn better that which attracts our attention, and emotion automatically makes us pay attention". This is what exercising songs do in a language-learning program.

Thain (2010) also found that listening to songs could facilitate the development of the four skills, activation of hemispheres, memory, motivation, and cultural sensitivity. This supports the second finding of the present study stressing the point that both speaking and reading-aloud of the learners could be positively affected. In an almost similar study, Slevc and Miyake (2006) found that those adult students with more advanced musical aptitudes spoke English with better pronunciation than those with less developed aptitudes. This is relatively what we tried to do in this study. Using and developing the musical intelligence of the learners described in the theory of multiple intelligences by Gardner (1983), in a couple of purviews related to our study such as sound and rhythm sensitivity and connection of the words in order to attain a more fluent and natural speaking and reading-aloud. Moreover, the classroom discussions with the learners and the findings of the present research show that singing songs in English highly affected their pronunciation and connected speech.

\section{Conclusion}

The outcome of the posttest data analysis clarified that the participants receiving English verbal songs as a partial recreational activity in surface but a pedagogical activity in depth, significantly outperformed the subjects in the control group. Therefore, it is generalized that receiving English verbal songs and its related strategies significantly affect the connected speech and pronunciation of Iranian intermediate EFL learners. Based on the present findings, verbal songs 
provide the learners with a pleasant atmosphere of gradual language development; they reduce the learners' stresses and create a cooperative ambience and unison among the learners. Songs could be a promising replace for the traditional methods of teaching pronunciation such as listening and repeating individual words in isolation. Songs are suitable authentic teaching aid and interesting enough for almost every human being to benefit even in the course of learning and improving language skills.

Concisely, it can be concluded that singing songs could generally have significant impacts on the connected speech aspects of the second language learners' speech production. Further researches are needed to investigate the other methods with the purpose of measuring the effects of employing target language songs in different genres on development of different phonological aspects of the target-spoken language. If the results of this study are supported by further researches, then it can safely be argued that using songs and their related tasks energized by specific strategies are of great importance in the process of developing the EFL learners' second language speaking skill. The teachers would hopefully take what has been presented here and apply it to their own situations in order to improve naturalness and fluency of their students' speaking in the target language.

\section{References}

Abbott, M. (2002). Using music to promote L2 learning among adult learners. TESOL Journal, 11(1), 10-17.

Abeles, H., Hoffer, C., \& Klotman, R. (1994). Foundations of music education. New York: Shirmer Books.

Abrate, J. H. (1983). Pedagogical applications of the French popular song in the foreign language classroom. Modern Language Journal, 67, 8-12.

Adkins, S. (1997). Connecting the powers of music to the learning of languages. Journal of Imagination in Language Learning, 4, 40-48.

Aida, Y. (1994). Examination of Horowitz, Horowitz, \& Cope's construct of foreign language anxiety: The case of students in Japanese. Modern Language Journal, 78, 155-168.

Akmajian, A., Demers, R.A., Farmer, A.K., \&Harnish, R.M. (2001). Linguistics: an introduction to language and communication (5th ed.). Cambridge, Mass: MIT Press.

Amiri, M. (2000). A study on the English language programs at B.A. level at Tehran universities. Master thesis, Allameh Tabatabai University, Tehran, Iran.

Anderson-Hsieh, J., Riney, T., \& Koehler, K. (1994). Connected speech modifications in the English of Japanese ESL learners. Issues and Developments in English and Applied Linguistics, 7, 31-52.

Anton, R. J. (1990). Combining singing and psychology. Hispania, 73, 1166-1170.

Arellano, S. I., \& Draper, J. E. (1972). Relations between musical aptitudes and second-language learning. Hispania, $55,111-121$.

Arleo, A. (2000). Music, song, and foreign language teaching. Les Cahiers de l'APLIUT, 19, 5-19.

Arnold, Jane.(ed). Affect in Language Learning. Cambridge: Cambridge University Press, 1999.

Balter, M. (2001). Language, brain, and cognitive development meeting: what makes the mind dance and count? Science, 292, 1636-1637.

Bancroft, W.J. (1982). The Tomatis method and Suggestopedia: A comparative study. International Conference of the Society for Accelerative Learning and Teaching, seventh Colorado, April 30-May 2, 1982.

Bancroft, W.J. (1985). Music therapy and education. Journal of the Society for Accelerative Learning and Teaching, 10 (1), 3-19.

Bartle, G. (1962). Music in the language classroom. Canadian Modern Language Review, 19 (1), 11-13.

Besson, M. (1998). Meaning, structure, and time in language and music. Cahier de Psychologie Cognitive, 17, 921-950.

Birjandi, P., \&Rahimi, A. H. (2012). The effect of metacognitive strategy instruction on the listening performance of EFL students. International Journal of Linguistics, 4(2), 495-517.

Bowen, J. (1976). Current research on an integrative test of English Grammar. RELC Journal, 7, 30-37.

Brown, H. (2001). Teaching by principles: An interactive approach to language pedagogy (2 ${ }^{\text {nd }}$ ed.), New York: Longman.

Brown, J. D., \&Hilferty, A. (1986a). Listening for reduced forms. TESOL Quarterly, 20, 759-763.

Brown, J. D., \&Hilferty, A. (1986b). The effectiveness of teaching reduced forms for listening comprehension. RELC Journal, 17, 59-70.

Brown, J. D., \&Hilferty, A. (2006). The effectiveness of teaching reduced forms for listening comprehension. In J. D. Brown, \& K. Kondo-Brown, (Eds.), Perspectives on teachingconnected speech to second language speakers (pp. 5158). Honolulu, HI: University of Hawai 'i, National Foreign Language Resource Center.

Brown, J. D., \& Kondo-Brown, K. (Eds.). (2006). Perspectives on teaching connected speech to second language speakers. Honolulu, HI: University of Hawai ${ }^{i} i$, National Foreign LanguageResource Center. 
Bruner, J. (1960). The process of education. New York: Vintage Books.

Celce-Murcia, M., Brinton, D., \& Goodwin, J. (1996). Teaching pronunciation: A reference for teachers of English to speakers of other languages. New York: Cambridge University Press.

Chan, A.S., Ho, Y.C., \& Cheung, M.C. (1998). Music training improves verbal memory. Nature, 396 (6707), 128.

Chazin, S., \&Neuschatz, J. S. (1990). Using a mnemonic to aid in the recall of unfamiliar information. Perceptual and Motor Skills, 71, 1067-1071.

Claerr, T., \&Gargan, R. (1984). The role of songs in the foreign language classroom. OMLTA Journal, 28-32. Also in Snyder, B. (Ed.), Look Out World, Here We Come! (Eric Document Reproduction No. ED 254 104)

Cormier, A. (1985). The relationship between music and French as a second language. Unpublished Master's Thesis, University of Western Ontario, London.

Crookes, G., \& Schmidt, R.W. (1991). Motivation: Reopening the research agenda. Language Learning, 41, $469-512$.

Crystal, D. (2008). Dictionary of linguistics and phonetics $\left(6^{\text {th }}\right.$ ed.). Oxford: Blackwell

Dauer, R., \& Browne, S. (1992). Teaching the pronunciation of connected speech. Paper presented at the 26th annual meeting of TESOL, Vancouver, BC (ERIC Document Reproduction Service No. ED354777).

Dejuán, M. (1997). Coleccióncomplementosseriedidáctica: la comunicación en la clase de españolcomolenguaextranjera (Supplementary teaching series: Communication in the Spanish class). Madrid, España: La Factoría de ediciones.

Deliére, J., \& Lafayette, R. C. (1985). La Clef des chants: thèmesculturelset techniques pédagogiques pour l'enseignement de la civilisation par la chanson (Songs are the key: Cultural themes and pedagogical techniques for teaching via song). The French Review, 58, 411-425.

Denham, K., \&Lobeck, A. (2010). Linguistics for everyone. Boston: Cengage/Wadsworth.

Deutsch, D. (1991). The tritone paradox: an influence of language on music perception. Music Perception, 8, $335-347$.

Developing pronunciation through songs. (2006). Published on

http://www.teachingenglish.org.uk, retrieved October 20, 2013 from

http://www.teachingenglish.org.uk/articles/developing-pronunciation-through-songs

Dexter, E. S. (1934). Pitch discrimination and French accent on the high school level. Journal of Applied Psychology, $17,717-720$.

Dominguez, D. (1991). Developing language through a musical program and its effect on the reading achievement of Spanish-speaking migrant children. Unpublished Doctoral Dissertation, Western Michigan University, Kalamazoo.

Eckman, F. R., Iverson, G. K., \& Song, J. Y. (2014). Covert contrast in the acquisition of second language phonology. Perspectives on Phonological Theory and Development: In honor of Daniel A. Dinnsen, 56, 25.

Ehri, L. C., Nunes, S. R., Willows, D. M., Schuster, B. V., Yaghoub-zadeh, Z., \& Shanahan, T. (2001). Phonemic awareness instruction helps children learn to read: Evidence from the National Reading Panel's meta-analysis. Reading Research Quarterly, 36, 250-287.

Elliot, A. R. (1995). Field independence/dependence, hemispheric specialization, and attitude in relation to pronunciation accuracy in Spanish as a foreign language. Modern Language Journal, 79, 356-371.

Eterno, J. A. (1961). Foreign language pronunciation and musical aptitude. Modern Language Journal, 45, 168-170.

Falioni, J. W. (1993). Music as means to enhance cultural awareness and literacy in the foreign language classroom. Mid-Atlantic Journal of Foreign Language Pedagogy, 7, 97-108. (Eric Document Reproduction No. ED 355 796)

Fiske, H. (1993). Music and mind: The concept of mind in music cognition. Canadian Music Educator, 34 (3), 15-26.

Fitzgerald, L.A. (1994). A musical approach for teaching English reading to limited English speakers. Unpublished Master's Thesis, National-Louis University. (Eric Document Reproduction No. ED 371 571).

Fonseca Mora, C. (2000). Foreign language acquisition and melody singing. English Language Teaching Journal, 54, 146-152.

Fonseca-Mora, C. Toscano-Fuentes, C., \&Wermke, K. (2011).Melodies that help: The

Relation between language aptitude and musical intelligence. Anglistik International

Journal of English Studies, 22(1), 101-118.

Foster, M. (1993). Suivez le rhythm..Le Françaisdans le Monde, 261, 58-63.

Gagné, R. M. (1977). The conditions of learning (3rd ed). New York: Holt, Rinehart, and Winston.

García-Sáez, S. (1984). The use of song in class as an important stimulus in the learning of a language. Paper presented at the annual meeting of the Southwest Conference on the Teaching of Foreign Languages, Colorado Springs, CO, March 1-3. (Eric Document Reproduction No. ED 240 872)

Gardner, H. (1985). Frames of mind: The theory of multiple intelligences. New York: Basic Books Inc. 
Gatti-Taylor, M. (1980). Songs as a linguistic and cultural resource in the Intermediate Italian class. Foreign Language Annals, 6, 465-469.

Gfeller, K. (1983). Musical mnemonics as an aid to retention with normal and learning disabled students. Journal of Music Therapy, 20, 179-189.

Giauque, G. S. (1985). Foreign language acquisition and the study of music. Paper presented at the Department of Education through Northern Arizona University, Flagstaff. (Eric Document Reproduction No. ED 264 738)

Gilleece, F. L. (2006). An empirical investigation of the association between musical aptitude

and foreign language aptitude. Retrieved October 11, 2013 from

https://www.cs.tcd.ie/disciplines/intelligent_systems/clg/clg_web/Theses/gilleece.phd.pdf

Graham, R.S. (1969). The music of language and the foreign accent. The French Review, 42, 445-451.

Griffee, D. T. (1995). Songs in action. Hertfordshire: Phoenix.

Griffen, R. (1977). Teaching Hispanic culture through folk music. Hispania, 60, 942-945.

Guglielmino, L.M. (1986). The affective edge: using songs and music in ESL instruction. Adult Literacy and Basic Education, 10, 19-26.

Hagen, S. (2000). Sound advice: A basis for listening. New York: Pearson Education.

Hamblin, V. L. (1991). Le clip et le look: popular music in the 1980s. The French Review, 64, 805-816.

Hanser, S. B., Larson, S. C., \&O’Connel, A. S. (1983). The effect of music on relaxation of expectant mothers during labor. Journal of Music Therapy, 20, 50-58.

Heller, S., \& Campbell, W. (1981). Psychomusicology and psycholinguistics, parallel paths or separate ways? Psychomusicology, 1 (2), 3-14.

Henrichsen, L. (1984). Sandhi-variation: A filter of input for learners of ESL. Language Learning, 3, 103-126.

Hodges, D. A. (1980). Physiological responses to music. In D. A. Hodges (Ed.), Handbook of music psychology (pp. 393-400). Lawrence, KS: National Association for Music Therapy.

$\mathrm{Hu}$, C.F. (2003). Phonological memory, phonological awareness, and foreign language word learning. Language Learning, 53(3), 429-462.

Hurford, J.R. (1994). Grammar: A student's guide. Cambridge: Cambridge University Press.

Ito, Y. (2006a). The comprehension of English reduced forms by second language learners and its effect on input-intake process. In J. D. Brown, \& K. Kondo-Brown, (Eds.), Perspectives onteaching connected speech to second language speakers (pp. 67-81). Honolulu, HI: University of Hawai‘i, National Foreign Language Resource Center.

Ito, Y. (2006b). The significance of reduced forms in L2 pedagogy. In J. D. Brown, \& K. Kondo-Brown, (Eds.), Perspectives on teaching connected speech to second language speakers (pp. 17-25). Honolulu, HI: University of Hawai'i, National Foreign Language Resource Center.

Jackendoff, R. (1994). Patterns in the mind: language and human nature. New York: Basic Books, Harper Collins.

Johnson, F.C., Delarche M., wurr A., \& Edwards, J. (1995). The learner as course planner and director. Educational Resources Information Clearinghouse Document No. 421012.

Jolly, Y. (1975). The Use of songs in teaching foreign language. Modern Language Journal, 59, 11-14.

Jones, D. (2006). English pronouncing dictionary (17th Ed.). Cambridge: Cambridge University Press.

Kadota, S. (1987). The role of prosody in silent reading. Language Sciences, 9, 185-205.

Kansakar, T.R. (1998). A course in english phonetics. New Delhi: Orient Blackswan.

Karmier, L. (1984). Can Southeast Asian students learn to discriminate between English phonemes more quickly with the aid of music and rhythm? Language Key to Learning, 5, 41-48.

Knight, R.A. (2012). Phonetics: A coursebook. Cambridge: Cambridge University Press.

Krashen, S. (1985). The input hypothesis: issues and implications. New York: Laredo Publishing Company.

Kraus, N., \&Chandrasekaran, B. (2010). Music training for the development of auditory skills. Nature Reviews Neuroscience, 11(8), 599-605.

Leith, W. D. (1979). Advanced French conversation through popular music. The French Review, 52, 537-551.

Lowe, A. S. (1995). The Effect of the Incorporation of music learning into the second language classroom on the mutual reinforcement of music and language. Unpublished doctoral dissertation, University of Illinois, UrbanaChampaign.

Lowe, A.S. (1998). L'enseignement de la musiqueet de la langue seconde: Pistesd'intdgrationet consequences sur les apprentice sages. The Canadian Modern Language Review, 54, 218-238.

Lozanov, G. (1978). Suggestology and outlines of suggestopedy. New York: Gordon and Breach Publishing Company. Lyczak, R. A. (1979). The effects of exposure to a language on subsequent learning. Language and Speech, 22, 81-88. 
Mackey, A., \&Gass, S. M. (2005). Second language research: Methodology and design. New York:Routledge.

Marquart, C. (1992). Kodàly based choral development in a bilingual bicultural setting. Unpublished Project Report, University of Saint Thomas, St. Paul, MN.

Matsuzawa, T. (2006). Comprehension of English reduced forms by Japanese business people and the effectiveness of instruction. In J. D. Brown, \& K. Kondo-Brown, (Eds.), Perspectiveson teaching connected speech to second language speakers (pp. 59-66). Honolulu, HI: University of Hawai'i, National Foreign Language Resource Center.

McCarthy, W. G. (1985). Promoting language development through music. Academic Therapy, 21, 237-242.

McElhinney, M., \& Annett, J. (1996). Pattern of efficacy of a musical mnemonic on recall of familiar words over several presentations. Perceptual and Motor Skills, 82, 395-400.

McKenna, M. (1977). Songs for language study. Audiovisual Instruction, 22, 42.

McLaughlin, B. (Ed.). (2013). Second language acquisition in childhood: Volume 2: School-age Children. New York: Psychology Press.

Medina, S. L. (1990). The effects of music upon second language vocabulary acquisition. Paper presented at the Annual Meeting of the Teachers of English to speakers of other languages. San Francisco, CA. March. Also in National Network for Early Language Learning, 6, 6-8. (Eric Document Reproduction No. ED 352 834)

Medina, S. L. (1993). The effect of music on second language vocabulary acquisition. National Network for Early Language Learning, 6(3), 1-8.

Medina, S. L. (2003). Acquiring vocabulary through story-songs. MexTESOL Journal, 26(1), 7-

10.

Milovanov, R.,Tervaniemi, M., \&Gustafsson, M. (2004). The impact of musical aptitude in

foreign language acquisition: The $8^{\text {th }}$ International Conference on Music Perception and

Cognition, Evanston, IL. Adelaide, Australia

Morely, J. (1996). Second language speech/pronunciation: Acquisition, instruction, standards, variation and accent. In J. Alatis, C. Straehle, B. Gallenberger, \& M. Ronkin (Eds.), Georgetown University round table on languages \& linguistics (pp. 140-160). Washington, D. C.: Georgetown University.

Moreno, S., Marques, C., Santos, A., Santos, M., Castro, S., \&Besson, M. (2009). Musical training influences linguistic abilities in 8-year-old children: more evidence for brain plasticity. Cerebral Cortex, 19(3), 712-723.

Morgan, C. (2003). Musical aptitude and second-language phonetics learning: Implications for teaching methodology. Unpublished Doctoral Dissertation, Simon Fraser University, British Columbia.Retrieved October 11, 2013 from

http://summit.sfu.ca/system/files/iritems1/6519/b34634757.pdf

Morrongiello, B. A., \& Roes, C. L. (1990). Children's memory for new songs: Integration or independent storage of words and tunes? Journal of Experimental Psychology, 50, 25-38.

Moussoulides, E. (1986). Using songs and games in the language classroom. Proceedings of the National Modern Language Convention (Dublin, Ireland, January 31-February 1).

Murphey, T. (1987). English through singing, TPR, walking labs, and music matter. Paper presented at the annual meeting of the International Association of Teachers of English as a Foreign Language (Westende, Belgium, April 1214). (Eric Document Reproduction No. ED 287 292)

Murphey, T. (1990). The song stuck in my head phenomenon: A melodic Din in the LAD?' System, 18(1), 53-64.

Murphey, T. (2010). Gracias a la vida - musicaque me ha dado tanto: Songs as scaffolded-languaging for SLA. In A. Hermont, R. Esprito Santo \& S. Cavalcante (Eds.). Linguagem E Cognição (p. 241-255). Belo Horizonte: Ed.PUC Minas.

Nambiar, S. A. (1993). Pop songs in language teaching. In Oller, J. W. Jr. (Ed.), 2nd edition. Methods that work: Ideas for literacy and language teaching, (pp. 335-338). Boston: Heinle\&Heinle Publishers.

Nuessel, F., \&Cicogna, C. (1991). The integration of songs and music into the Italian curriculum. Italica, 68, 473-486.

Olhaver, D. (1998). Learning with music in the classroom: What research says.Montessori-Life, 10, 32-33.

Palmer, C., \& Kelly, M.H. (1992). Linguistic prosody and musical meter in song. Journal of Memory and Language, 3, 525-542.

Palmer, C., Large, E.W., Pollack, J.B., \& Kelly, M.H. (1992). Linguistic prosody and musical meter in song. Journal of Memory and Language, 31, 525-542.

Peretz, I., Patel A.D., Tramo, M., \&Labreque R. (1998). Processing prosodic and musical patterns: A neuropsychological investigation. Brain and Language, 61, 123-144.

Pimsleur, P., Stockwell, R. P., \&Comrey, A. L. (1969). Foreign language learning ability, Journal of Educational Psychology, 53, 15-26.

Pinel, S. (1990) Learning French through music. Ottawa: Canadian parents for French. 
Poliquin, G. (1988). La chanson et la correction phonetique (song and phonetic correction). International Center for Research on Biligualism. Laval University: Quebec. (Eric Document Reproduction No. ED 318 211)

Postovsky, V. (1974). Effects of delay in oral practice at the beginning of second language learning. Modern Language Journal, 58, 229-239.

Price, C. J. (2012). A review and synthesis of the first 20 years of PET and fMRI studies of heard speech, spoken language, and reading. Neuroimage, 62 (2), 816-47.

Prickett, C. A., \& Moore, R. S. (1991). The use of music to aid memory of Alzheimer's patients. Journal of Music Therapy, 28 (2), 101- 110.

Purcell, J. M. (1992). Using songs to enrich the secondary class. Hispania, 75, 192-196.

Restrepo, L.Y., \& Silverman, I.E. (2001). Osmotherapy in acute stroke: A call to arms. Stroke, 32, 811-812.

RezvaniKalajahi, S. A. (2012). Needs of an ESL context: A case study of Iranian graduate students. World Applied Sciences Journal, 17 (7), 870-873.

Richards, R. G. (1975). Singing: a fun route to a second language. The Reading Teacher, 29 (3), 283-285.

Rixon, S. (1986). Developing listening skills. Macmillan: Publishers Limited.

Rousseau, J. (1781). Essaisurl'origine des langues. Paris: GF-Flammarion.

Salcedo, C. S. (1996). Using multimedia to simulate the target culture: The closest thing to being there. Proceedings from the 1996 International Conference on Technology in Education, pp. 560-562. New Orleans: LA, March 24.

Salcedo, C.S. (2002). The effects of songs in the foreign language classroom on text recall and involuntary mental rehearsal. Unpublished Doctoral Dissertation, Louisiana State University.

Salcedo, S. C. (2010). The effects of songs in the foreign language classroom on text recall, delayed text recall, and involuntary mental rehearsal. Journal of college teaching and learning, 7 (6), 84-97.

Salzmann, Z. (2004). Language, culture, and society: An introduction to linguistic anthropology. Colorado/Oxford: Westview Press.

Schiffler, L. (1986). Music in teaching French by suggestopaedia. Rassegnaitalia di Linguistica, 18, 65-80.

Scovel, T. (1969). Foreign accents, language acquisition, and cerebral dominance. Language Learning, 19 (34), 245253.

Seife, C. (2000). Neuropsychology: Language affects sound perception. Science, 290, 2051-2052

Seong, Y.(n.d.). Evaluating an Instrument for assessing connected speech performance using

FACETS analysis. Retrieved October 18, 2013 from

http://w.davidcrystal.com/DC_articles/Linguistics46.pdf

Serafine, M. L., Crowder, R. G., \&Repp, B. (1984). Integration of melody and text in memory for songs. Cognition, 16, 285-303.

Serafine, M. L., Davidson, J., Crowder, R. G., \&Repp, B. (1986). On the nature of melody-text integration in memory for songs. Journal of Memory and Language, 25, 123-135.

Slevc, L. R., \& Miyake, A. (2006). Individual Differences in Second Language Proficiency: Does Musical Ability Matter? Psychological Science, 17, 675-681.

Sloboda, J. (1985). The musical mind: The cognitive psychology of music. New York: Oxford Science.

Sloboda, J. (1989). The musical mind: The cognitive psychology of music. New York: Oxford University Press.

Stansell, J.W. (2002). The use of music in learning languages: A review [online]. University of Illinois at UrbanaChampaign,2002.Retrievedfromwww.mste.uiuc.edu/courses/ci407su02/students/stansel//Literature\%20Review\%201.ht $\mathrm{m}$

Swain, J. (1986). The need for limits in hierarchical theories of music. Music Perception, 4, 121-148.

Techmeier, M. (1969). Music in the teaching of French. Modern Language Journal, 53, 96.

Thain, L.A. (2010). Rhythm, music, and young learners: A winning combination. In A. M. Stoke (ed.), Conference Proceedings (pp. 407-416). Tokyo: JALT.

Thorndike, E. L. (1913). Educational psychology (vol. two). New York: Teachers College Columbia University Publishers.

Tomatis, A. (1991). Nous sommextousnéspolyglottes. Paris: Fixot,

Trapp, E. A. (1991). Break down inhibitions and build up understanding with music, music, music. Hispania, 74, 437438.

Urbancic, A., \&Vizmuller, J. (1981). Using popular music in the language classroom. The Canadian Modern Language Review, 38, 81-87. 
Wallace, W. T. (1994). Memory for music: effect of melody on recall of text. Journal of Experimental Psychology: Learning, Memory, and Cognition, 20, 1471-1485.

Weinstein, N. (2001). Whaddaya say. Guided practice in relaxed speech (2nd Ed.). New York: Longman.

Willis, B. D., \& Mason, K. (1994). Canciones en la clase: The why and how of integrating songs in Spanish by English speaking and bilingual artists. Hispania, 77, 102-109.

Wu, L., \& McMahon, M. (2014). Adopting a musical intelligence and e-Learning approach to improve the English language pronunciation of Chinese students. $A I \&$ society, 29(2), 231-240.

Zimny, G. H., \&Weidenfeller, E. W. (1963). Effects of music upon GSR and heartrate. American Journal of Psychology, 76, 311-314.

Zola, M., \&Sandvoss, J. (1976). Song in second-language teaching: the uses of imagery. The Canadian Modern Language Review, 33, 73-85. 